\title{
Editorial
}

KOLESNYKOVA T. O.

Editor-in-Chief,

PhD Social. Sciences, Communication, Senior researcher,

Director of the Scientific and Technical Library

Dnipro National University of Railway Transport

named after Academician V. Lazaryan (Dnipro, Ukraine),

e-mail chief.library@gmail.com, ORCID 0000-0002-4603-4375

\section{UNIVERSITY LIBRARY IN THE DEVELOPMENT OF DIGITAL INFRASTRUCTURE OF SCIENCE AND EDUCATION}

\author{
Presented a new 4 (2019) issue of conference proceedings "University Library at a New Stage of Social \\ Communications Development” \\ Keywords: university library; conference proceedings
}

Dear readers, authors, colleagues!

Today we are presenting the new (IV) issue of Conference Proceedings journal University Library at a New Stage of Social Communications Development (UniLibNSD). New in all respects - in terms of format, editorial board, and the ability to integrate into the global information space.

This is a publication about communication and for communication, the papers for which were selected by Scientific Committee of the UniLibNSD International Conference and recommended by the Editorial Board.

The International Conference was initiated by Scientific and Technical Library of Dnipro National University of Railway Transport named after Academician V. Lazaryan (DNURT Library; https://library.diit.edu.ua) and took place on October 3-4, 2019 in the DNURT Conference Hall (Dnipro, Ukraine; http://conflib.diit.edu.ua/Conf_univ_Library).

Active co-organizers of the Conference are the Scientific Library of the Belarusian National Technical University, the Republic of Belarus (Director Inna Yurik) and the Nazarbayev University Library, the Republic of Kazakhstan (Director Asemgul Temyrxanova). Strategic Partner is Ukrainian Library Association.

Field of science and issues in focus: The conference proceedings present the latest achievements in practice and research in the field of library and information science - revealing emerging trends and new ideas before they appear in peer-reviewed journals. Conference proceedings offer broad coverage of new ideas, methodologies and projects in fast-moving areas of research related to the activity of university libraries in education, science and culture.

Libraries in the age of transition to the digital economy and digital society are often pioneers in their universities in organizing and implementing digital scholarly and educational communication initiatives. Deciding to strengthen their position at universities, they are not afraid to experiment, challenge the status quo, and launch new services to meet the needs of new users and new strategies for developing their institutions (Bains, 2017; Kolesnykova \& Matveyeva, 2019).

The theme of the UniLibNSD 2019 Conference is "University Library in the Development of Digital Infrastructure of Science and Education”.

The main issues proposed for discussion: - Strategic partnership; • Management and marketing of higher institution libraries; - Library collections: traditional and electronic resources; acquisition; scientific processing; using; digitization and digital preservation of 
collections; - Library services to support university science: digital library publishing; open access repositories; copyright and open access problems; evaluation of scientific resources: bibliometrics, scientometrics, new and emerging metrics; - Change of roles: from information providers to teachers; • The contribution of theory and research to the libraries transformation

The Conference Proceedings Journal University Library at a New Stage of Social Communications Development provides direct open access to its content, based on the following principle: free open access to research results enhances global knowledge sharing.

The international editorial board appreciates the contribution of each author. We sincerely thank our readers for their interest in UniLibNSD, our reviewers for their competence, delicacy and goodwill.

We sincerely wish our partners and readers success and confidence in tomorrow! We invite you to cooperate.

\section{REFERENCES}

Bains, S. (2017). The role of the library in scholarly publishing: The University of Manchester experience. Insights, 30(3), 70-77. https://doi.org/10.1629/uksg.380

Kolesnykova, T., \& Matveyeva, O. (2019). An Analysis of Digital Library Publishing Services in Ukrainian Universities. Evidence Based Library and Information Practice, 14(4), $52-$ 71. https://doi.org/10.18438/eblip29510

КОЛЕСНИКОВА Т. О.

Головний редактор, канд. наук із соціальних комунікацій, с.н.с., Директорка Науково-технічної бібліотеки, Дніпровський національний університет залізничного транспорту імені академіка В. Лазаряна (Дніпро, Україна), e-mail chief.library@gmail.com, ORCID 0000-0002-4603-4375

\section{БІБЛІОТЕКА УНІВЕРСИТЕТУ В РОЗВИТКУ ЦИФРОВОЇ ІНФРАСТРУКТУРИ НАУКИ І ОСВІТИ}

Було представлено новий 4 (2019) випуск матеріалів конференції “University Library at a New Stage of Social Communications Development”

Ключові слова: університетська бібліотека; матеріали конференції 